\title{
mRNA Expression of lipogenic enzymes in mammary tissue and fatty acid profile in milk of dairy cows fed flax hulls and infused with flax oil in the abomasum
}

\author{
Marie-France Palin, Cristiano Côrtesł, Chaouki Benchaar, Pierre Lacasse and Hélène V. Petit* \\ Dairy and Swine Research and Development Centre, Agriculture and Agri-Food Canada, Sherbrooke, QC, Canada J1M OC8
}

(Submitted 14 May 2013 - Final revision received 26 September 2013 - Accepted 3 October 2013 - First published online 13 November 2013)

\section{Abstract}

In the present study, the effect of flax hulls with or without flax oil bypassing the rumen on the expression of lipogenic genes in the mammary tissue of dairy cows was investigated. A total of eight dairy cows were used in a replicated $4 \times 4$ Latin square design. There were four periods of $21 \mathrm{~d}$ each and four treatments: control diet with no flax hulls (CONT); diet with $9.88 \%$ flax hulls in the DM (HULL); control diet with $500 \mathrm{~g}$ flax oil/d infused in the abomasum (COFO); diet with $9.88 \%$ flax hulls in the DM and $500 \mathrm{~g}$ flax oil/d infused in the abomasum (HUFO). A higher mRNA abundance of sterol regulatory element binding transcription factor, fatty acid (FA) synthase, lipoprotein lipase $(L P L), P P A R \gamma 1$, stearoyl-CoA desaturase (SCD) and acetyl-coenzyme A carboxylase- $\alpha$ was observed in cows fed HULL than in those fed CONT, and HUFO had the opposite effect. Compared with CONT, COFO and HUFO lowered the mRNA abundance of $S C D$, which may explain the lower proportions of MUFA in milk fat with flax oil infusion. The mRNA abundance of $L P L$ in mammary tissue and proportions of long-chain FA in milk fat were higher in cows fed COFO than in those fed CONT. The highest proportions of trans FA were observed when cows were fed HULL. The present study demonstrates that flax hulls with or without flax oil infusion in the abomasum can affect the expression of lipogenic genes in the mammary tissue of dairy cows, which may contribute to the improvement of milk FA profile.

\section{Key words: Antioxidants: Fatty acids: Flaxseed: Gene expression: Lignans: Mammary tissue}

The inclusion of dietary fatty acid (FA), especially PUFA, may play an important role in oxidative metabolism. Indeed, the administration of PUFA has been shown to increase the risk of plasma lipoperoxidation in ruminant animals such as steers ${ }^{(1)}$ and sheep ${ }^{(2)}$. Although oxidative metabolism is essential for the survival of cells, a side effect of this dependence is the production of free radicals and other reactive oxygen species that cause oxidative changes. Sies et al. ${ }^{(3)}$ suggested that antioxidants are required to provide protection against the oxidative effect of diets rich in fat. The inclusion of antioxidants in the diet alleviates the negative effects of oxidised fat by scavenging peroxides and reducing FA peroxidation $^{(4)}$ and enhances the lactation performance and antioxidant status of cows ${ }^{(5)}$. It is well known that highproducing dairy cows are prone to oxidative stress and that this situation can be exacerbated under certain environmental, physiological and dietary conditions ${ }^{(6)}$. Strong positive correlations between several antioxidant enzymes and vascular adhesion molecules indicate a protective response of antioxidants to the enhanced proinflammatory state observed in transition dairy cows ${ }^{(7)}$. Some antioxidants such as sesamin lignans also increase the expression of genes involved in $\beta$-oxidation in rats $^{(8)}$ and modulate the transcript abundance of lipogenic genes such as lipoprotein lipase ( $L P L)$ and stearoyl-CoA desaturase $(S C D)$ in adipose tissue and of the acetyl-coenzyme A carboxylase- $\alpha$ (ACACA) in the liver ${ }^{(9)}$. Antioxidants could thus contribute to the enhancement of mechanisms protecting against oxidative stress with various immunity, reproduction and health benefits. Therefore, the inclusion of natural antioxidants in cows' diet appears interesting for exploiting the full potential of PUFA while decreasing oxidative stress.

Abbreviations: ACACA, acetyl-coenzyme A carboxylase- $\alpha$; ADF, acid-detergent fibre; COFO, control diet with $500 \mathrm{~g}$ flax oil/d in the abomasum; CONT, control diet with no flax hulls; FA, fatty acids; FASN, fatty acid synthase; HUFO, diet with $10 \%$ flax hulls and $500 \mathrm{~g}$ flax oil/d in the abomasum; HULL, diet with $10 \%$ flax hulls; LPL, lipoprotein lipase; NDF, neutral-detergent fibre; SCD, stearoyl-CoA desaturase; SREBF1, sterol regulatory element binding transcription factor 1; VFA, volatile fatty acids.

* Corresponding author: Dr H. V. Petit, fax +1 8197807210 , email helene.petit@agr.gc.ca

† Present address: Unité de Recherche Systèmes d'Élevage, Département de Productions Animales, École Supérieure d'Agriculture d'Angers, Angers 49007, France. 
Research has demonstrated several health benefits of $n-3$ FA in humans including the prevention of $\mathrm{CVD}^{(10)}$ and reduction of the incidence of breast and prostate cancers ${ }^{(11)}$. Thus, supplementation with PUFA from the $n-3$ family has been used as a strategy to increase these FA in animal products to improve their nutritive value ${ }^{(12,13)}$. In dairy cows, flaxseed, which is rich in the $n$-3 linolenic acid, has been shown to decrease the proportions of SCFA and medium-chain FA and to increase those of PUFA in milk fat ${ }^{(14)}$. However, lipid oxidation of milk is highly influenced by the content of long-chain FA, which are particularly susceptible to oxidation and can give rise to the development of off-flavour ${ }^{(15)}$

Plant lignans are natural strong antioxidants, and flaxseed (Linum usitatissimum) is known as the richest dietary source of lignans, including matairesinol and glycosides of secoisolariciresinol as the major compounds ${ }^{(16)}$. In dairy cows, rumen microbiota converts plant lignans into mammalian lignans such as enterolactone, which are later absorbed and transferred into urine, blood and milk ${ }^{(17)}$. The greatest concentration of enterolactone in milk is obtained when flax meal and not flax seed is added to the diet of dairy cows ${ }^{(18)}$, as lignans are concentrated in the outer fibre-containing layers ${ }^{(19)}$. The mammalian lignan enterolactone has been shown to have greater antioxidant activity than vitamin $\mathrm{E}^{(20)}$, which suggests that flax may contribute to the enhancement of the oxidative status of cows provided PUFA supplementation. Indeed, recent results have indicated that supplementation of $n-3$ PUFA along with antioxidants such as vitamin $\mathrm{E}$ and plant polyphenols reduces lipoperoxidation in lactating cows, thereby contributing to their protection against the deleterious consequences of lipoperoxidation ${ }^{(21)}$. Besides the well-known antioxidant properties of plant lignans, recent papers have also reported their effects on the expression of lipogenic genes. For example, higher hepatic mRNA abundance of sterol regulatory element binding transcription factor 1 (SREBF1), fatty acid synthase $(F A S N)$ and $A C A C A$ has been observed in rats fed green tea, which is rich in the lignans matairesinol and secoisolariciresinol $^{(22)}$. We have recently shown that flax hulls, which are rich in lignans, increase the mammary transcript abundance of some antioxidant genes (e.g. catalase, glutathione peroxidase 1 and superoxide dismutase 1), which can contribute to the protection against oxidative stress damage occurring in the mammary gland of dairy cows ${ }^{(23)}$. However, the effect of flax hulls on the expression of lipogenic genes has never been investigated. Taking all these results into account, we hypothesised that the inclusion of a source of antioxidants such as flax lignans to the diet of dairy cows supplemented with PUFA may modulate the mammary expression of genes involved in the metabolism of lipids, thus affecting milk FA profile. Therefore, the present study aimed to determine whether dietary flax hulls with or without flax oil bypassing the rumen can affect the expression of lipogenic genes in mammary tissue. The effects of flax hulls and flax oil on milk production and composition, milk FA profile and ruminal fermentation were also determined.

\section{Materials and methods}

\section{Animals and experimental treatments}

The present study is part of a larger project where results on mammary gene expression and activity of antioxidant enzymes, along with the concentration of the mammalian lignan enterolactone in milk and plasma, have been reported previously ${ }^{(23)}$. A total of eight multiparous Holstein cows fitted with ruminal cannulas $(10 \mathrm{~cm}$; Bar Diamond, Inc.) with milk production averaging 163 (SE 11) d were assigned to a replicated $4 \times 4$ Latin square design with four $21 \mathrm{~d}$ periods balanced for residual effect. Treatments were planned according to a $2 \times 2$ factorial arrangement: control diet with no flax hulls (CONT); diet with $9.88 \%$ flax hulls in the DM (HULL); control diet with $500 \mathrm{~g}$ flax oil/d infused in the abomasum (COFO); diet with $9.88 \%$ flax hulls in the DM and $500 \mathrm{~g}$ flax oil/d infused in the abomasum (HUFO). The two total mixed diets have been described in detail previously ${ }^{(23)}$ and have been formulated to meet the requirements of cows that were $750 \mathrm{~kg}$ in body weight and producing $30 \mathrm{~kg}$ milk/d with $3.5 \% \mathrm{fat}^{(24)}$. Diets with and without flax hulls had equal amounts of protein, acid-detergent fibre (ADF) and neutraldetergent fibre (NDF), but the addition of flax hulls to the diets resulted in a higher concentration of fat compared with the control diet $(5.46 v .2 .73 \%$ of the DM). The fatty acid composition of flax oil (Brenntag Canada, Inc.) and chemical composition of flax hulls (Natunola Health, Inc.) have been provided in detail by Côrtes et $a l .^{(23)}$. Flax hulls contained $29.8 \%$ of total lipids and $0.99 \%$ of secoisolariciresinol diglucoside on a DM basis. The FA profile of flax hulls, expressed as a percentage of total FA, included $8.2 \%$ of $16: 0$, $1 \cdot 7 \%$ of $18 \cdot 0,16 \cdot 6 \%$ of cis- $918: 1,15 \cdot 4 \%$ of cis- $618: 2$ and $58.1 \%$ of cis-3 $18: 3$. At the start of the experiment, the body weight of the cows averaged 742 (SE 11) kg. The cows were kept in individual stalls and were given free access to water. National guidelines for the care and use of animals were followed as recommended by the Canadian Council on Animal Care ${ }^{(25)}$, and all experimental procedures were approved by the local Animal Care Committee.

\section{Sampling}

Each experimental period consisted of $21 \mathrm{~d}$ with $7 \mathrm{~d}$ of adaptation to the diets and $14 \mathrm{~d}$ of infusion. The cows were milked twice a day at 08.00 and 19.00 hours and were fed ad libitum (10\% refusals on an as-fed basis) twice a day (08.30 and 14.30 hours). Feed intake and milk yield were measured daily throughout the experimental period. Abomasal infusions were carried out by inserting an infusion line through the rumen cannula and the sulcus omasi into the abomasum as described previously ${ }^{(23)}$. Samples of diets and of flax hulls were collected daily from day 15 to day 20 and pooled within a period for each cow. Samples were frozen at $-20^{\circ} \mathrm{C}$ for subsequent drying at $55^{\circ} \mathrm{C}$ and analysed according to the procedures used by Côrtes et al ${ }^{(26)}$. Milk samples were obtained from each cow from day 15 to day 21 and pooled on a yield basis. Some samples were kept frozen without a preservative for further analysis of milk FA 
profile, whereas some samples were stored at $4^{\circ} \mathrm{C}$ with a preservative (bronopol-B2) until analyses of protein, fat, urea $\mathrm{N}$, lactose and total solids and somatic cell count.

Faecal output and digestibility were predicted by inserting a capsule of $\mathrm{Cr}_{2} \mathrm{O}_{3}$ into the rumen once daily at 09.00 hours from day 11 to day $20\left(10 \mathrm{~g} \mathrm{Cr}_{2} \mathrm{O}_{3} / \mathrm{d}\right)$. Oil infused in the abomasum was prepared daily for each cow and weighed into tarred bottles. Therefore, the exact amount of oil used for infusion was considered as intake for the determination of diethyl ether extract digestibility. Faecal grab samples were collected twice daily from day 15 to day 20 at 08.30 and 16.30 hours. Faecal samples were then processed as described by Côrtes et $a l^{(27)}$. On day 20, ruminal contents were collected at 0,1 , 2, 4 and $6 \mathrm{~h}$ after the morning meal, and the $\mathrm{pH}$ was immediately monitored as described previously ${ }^{(26)}$. The ruminal contents were then strained through four layers of cheesecloth, and the filtrate was acidified to $\mathrm{pH} 2$ with $50 \%$ $\mathrm{H}_{2} \mathrm{SO}_{4}$ and kept at $-20^{\circ} \mathrm{C}$ for the determination of volatile fatty acid (VFA) and $\mathrm{NH}_{3}-\mathrm{N}$ concentrations. On day 21, biopsies (approximately $800 \mathrm{mg}$ ) were taken from the upper portion of the mammary gland on the last day of each period as described previously ${ }^{(28)}$.

\section{Chemical analyses}

DM content of the diets and faeces was determined in a forced-air oven according to procedure 934.01 ${ }^{(29)}$. Total mixed dried diets and freeze-dried faeces were ground to pass through a $1 \mathrm{~mm}$ screen in a Wiley mill before analyses of total N, diethyl ether extract, ADF and NDF. The analyses of total N, diethyl ether extract, ADF and NDF were carried out as described previously by Côrtes et al. ${ }^{(26)}$. Faecal samples were analysed for chromium according to the procedure of Fenton \& Fenton ${ }^{(30)}$. The concentrations of $\mathrm{NH}_{3}-\mathrm{N}$ and VFA in ruminal fluid were determined, respectively, using the indophenolblue method ${ }^{(31)}$ and a HPLC Waters Alliance 2695 system (Waters) fitted with a flame-ionisation detector. The concentration of milk fat was determined by the method of Rose-Gottlieb $^{(29)}$. The concentrations of protein, lactose and urea $\mathrm{N}$ in the milk samples were determined by IR spectrophotometry (System 4000 Milkoscan; Foss Electric) following procedure 972.16 of the Association of Official Analytical Chemists $^{(29)}$. Milk fat was extracted and FA were methylated according to the method of Chouinard et al. ${ }^{(32)}$, while in situ transesterification of the diets was carried out according to the method of Park \& Goins ${ }^{(33)}$. Individual FA were identified according to the procedures described by Côrtes et al. ${ }^{(26)}$ and trans-10 18:1 were coeluted with trans-11 18:1.

\section{Real-time quantitative RT-PCR amplifications of the studied genes}

Total RNA was extracted from biopsies using TRIzol Reagent (Invitrogen Life Technologies). The synthesis of complementary DNA and quantification of mRNA abundance in mammary gland biopsies were carried out as described previously by Labrecque et al. ${ }^{(34)}$. Primer pairs were designed using the Primer express software 3.0 (PE Applied BioSystems). The studied genes were SREBPF1, FASN, LPL, PPAR 1 1, PPAR $\gamma 2$, $S C D$ and $A C A C A$. Table 1 summarises the primer sequences, GenBank accession numbers, amplified product sizes, primer concentrations used and amplification efficiencies (\%) for all the studied genes. Moreover, three reference genes were used to identify the gene that was the least affected by the treatments. These reference genes were glyceraldehyde-3-phosphate dehydrogenase (GAPDH), peptidylproplyl isomerase A (PPIA) and actin $\beta(A C T B)$. The $A C T B$ gene was identified as the best reference gene for the normalisation of the data sets of the present study according to the NormFinder statistical algorithm $^{(35)}$. Data were analysed using the comparative $C_{\mathrm{t}}$

Table 1. Primer sequences used for real-time quantitative PCR amplifications of the studied genes in mammary tissue

\begin{tabular}{|c|c|c|c|c|c|}
\hline Genes & Primer sequences $\left(5^{\prime}-3^{\prime}\right)$ & GenBank accession no. & Product size (nt) & Primer (nм) & Amplification efficiency (\%) \\
\hline SREBF1 & $\begin{array}{l}\text { F: TTTCTTCGTGGATGGCAACTG } \\
\text { R: TGCTCGCTCCAAGAGATGTTTC }\end{array}$ & NM_001113302 & 130 & $\begin{array}{l}300 \\
150\end{array}$ & $103 \cdot 80$ \\
\hline FASN & $\begin{array}{l}\text { F: AGCCCCTCAAGCGAACAGT } \\
\text { R: CGTACCTGAATGACCACTTTGC }\end{array}$ & NM_001012669 & 100 & $\begin{array}{l}300 \\
300\end{array}$ & $97 \cdot 82$ \\
\hline$L P L$ & $\begin{array}{l}\text { F: TAAGGCCTACCGGTGCAATTC } \\
\text { R: CTTGTTGATCTCGTAGCCCATGT }\end{array}$ & NM_001075120 & 100 & $\begin{array}{l}300 \\
300\end{array}$ & $92 \cdot 46$ \\
\hline$P P A R \gamma 1$ & $\begin{array}{l}\text { F: AAGTCCCCTTGCTTAGTTGTTCAG } \\
\text { R: AGGAATGACACTTGTTTACGGAAAC }\end{array}$ & Y12419 & 102 & $\begin{array}{l}300 \\
300\end{array}$ & $99 \cdot 51$ \\
\hline PPAR $\gamma 2$ & $\begin{array}{l}\text { F: TGAACGGAACTGGCCTTTTTG } \\
\text { R: TCCCAGAGTTTCACCCATCAC }\end{array}$ & Y12420 & 94 & $\begin{array}{l}900 \\
900\end{array}$ & $90 \cdot 72$ \\
\hline$S C D$ & $\begin{array}{l}\text { F: CCTGTGGAGTCACCGAACCT } \\
\text { R: GGTCGGCATCCGTTTCTG }\end{array}$ & NM_173959 & 146 & $\begin{array}{l}300 \\
300\end{array}$ & $106 \cdot 10$ \\
\hline$A C A C A$ & $\begin{array}{l}\text { F: GAGTTCCTCCTTCCCATCTACCA } \\
\text { R: GGTGCGTGAAGTCTTCCAATC }\end{array}$ & NM_174224 & 123 & $\begin{array}{l}300 \\
300\end{array}$ & $90 \cdot 31$ \\
\hline GAPDH & $\begin{array}{l}\text { F: TGACCCCTTCATTGACCTTCA } \\
\text { R: AACTTGCCGTGGGTGGAAT }\end{array}$ & BTU85042 & 66 & $\begin{array}{l}300 \\
150\end{array}$ & $97 \cdot 83$ \\
\hline PPIA & $\begin{array}{l}\text { F: GAGCACTGGAGAGAAAGGATTTG } \\
\text { R: GGCACATAAATCCCGGAATTATT }\end{array}$ & AF228021 & 71 & $\begin{array}{l}300 \\
300\end{array}$ & $96 \cdot 56$ \\
\hline ACTB & $\begin{array}{l}\text { F: GCGTGGCTACAGCTTCACC } \\
\text { R: TTGATGTCACGGACGATTTC }\end{array}$ & AY141970 & 54 & $\begin{array}{l}300 \\
300\end{array}$ & $93 \cdot 20$ \\
\hline
\end{tabular}

nt, Nucleotides; SREBF1, sterol regulatory element binding transcription factor $1 ; \mathrm{F}$, forward; $\mathrm{R}$, reverse; $F A S N$, fatty acid synthase; $L P L$, lipoprotein lipase; $S C D$, stearoyl-CoA desaturase (delta-9-desaturase); ACACA, acetyl-CoA carboxylase- $\alpha$; GAPDH, glyceraldehyde-3-phosphate dehydrogenase; PPIA, peptidylproplyl isomerase A; ACTB, actin $\beta$. 
method, and amplification efficiencies were determined as described previously by Côrtes et al. ${ }^{(23)}$.

\section{Statistical analysis}

All the results were analysed using the MIXED procedure of SAS (SAS 2000; SAS Institute, Inc.) within a $2 \times 2$ factorial arrangement of treatments. Data on faecal output and feed intake were averaged over the $6 \mathrm{~d}$ of the digestibility week (e.g. day 15 to day 20) and subjected to ANOVA. Data on milk production, milk composition, mRNA abundance and feed intake were analysed using a replicated $4 \times 4$ Latin square design with the following general model:

$$
Y_{i j k l}=\mu+S_{i}+C_{j(i)}+P_{k}+H_{l}+O_{m}+\mathrm{HO}_{l m}+e_{i j k l m},
$$

where $Y_{i j k l}$ is the dependent variable, $\mu$ is the overall mean, $S_{i}$ is the fixed effect of square $(i=1-2), C_{j(i)}$ is the random effect of cow within a square $(j=1-4), P_{k}$ is the fixed effect of period ( $k=1-4), H_{1}$ is the fixed effect of hull treatment, $O_{m}$ is the fixed effect of oil treatment, $\mathrm{HO}_{l m}$ is the interaction and $e_{i j k l m}$ is the residual error. Data on ruminal fermentation and digestibility were analysed using a single $4 \times 4$ Latin square design. The model for ruminal fermentation characteristics $\left(\mathrm{pH}\right.$, VFA and $\left.\mathrm{NH}_{3}-\mathrm{N}\right)$ was augmented with time and time $\times$ treatment interaction for repeated measurements, and values are reported with their adjusted mean values with their standard errors. The two-sided level of significance was set at $P \leq 0.05$, although probability values up to $P<0 \cdot 1$ are reported if the data suggest a trend. Results are reported as least squares means with their standard errors. Real-time quantitative RT-PCR data were analysed using normalised mRNA quantities (e.g. normalised with $A C T B$ ) and are presented as relative quantification of mRNA abundance using the comparative $C_{\mathrm{t}}$ method and comparing treatments with CONT. The compound symmetry was used as the covariance structure.

\section{Results}

\section{DM intake and digestibility}

There was no interaction between flax hull supplementation and flax oil infusion for the intake of DM and digestibilities of DM, crude protein, ADF, NDF and diethyl ether extract (data not shown). The intake of $\mathrm{DM}$ and digestibilities of DM, crude protein, ADF and NDF were similar among the treatment groups. However, the intake of DM, expressed as a percentage of body weight, was lower $(P=0.05)$ in cows infused with flax oil. The digestibility of diethyl ether extract was higher $(P=0.03)$ in cows fed diets supplemented with flax hulls, whereas flax oil infusion had no effect.

\section{Ruminal fermentation characteristics}

There was no interaction between treatment and sampling time for ruminal fermentation characteristics. Therefore, only mean values for the $6 \mathrm{~h}$ ruminal sampling time are given in Table 2. Ruminal $\mathrm{pH}$ and $\mathrm{NH}_{3}-\mathrm{N}$ concentration were similar among the treatment groups. Flax hull supplementation had no effect on total VFA concentration and proportion of acetate, but it increased the proportion of propionate and decreased those of butyrate and valerate and the acetate:propionate ratio in the rumen. The proportion of isobutyrate tended ( $P=0.06)$ to decrease with flax hull supplementation. Abomasal infusion of flax oil decreased the concentration of VFA and proportions of propionate and increased those of acetate, butyrate and isobutyrate in the rumen. Flax oil infusion increased the acetate:propionate ratio and decreased the propionate:(acetate + butyrate) ratio in the rumen, while flax hull supplementation increased the propionate:(acetate + butyrate) ratio. There was an interaction between flax hull supplementation and flax oil infusion for the proportions of valerate and isovalerate; the lowest and highest proportions

Table 2. Ruminal fermentation characteristics of Holstein cows fed diets containing no flax hulls (CONT), $9.88 \%$ flax hulls (HULL), no flax hulls and infused with $500 \mathrm{~g} / \mathrm{d}$ flax oil in the abomasum (COFO) or $9.88 \%$ flax hulls and infused with $500 \mathrm{~g} / \mathrm{d}$ flax oil in the abomasum (HUFO)

(Mean values with their overall standard errors)

\begin{tabular}{|c|c|c|c|c|c|c|c|c|}
\hline & \multicolumn{4}{|c|}{ Treatment } & \multirow[b]{2}{*}{ SEM } & \multicolumn{3}{|c|}{$P$} \\
\hline & CONT & HULL & COFO & HUFO & & Hull & Oil & Interaction \\
\hline $\mathrm{pH}$ & 6.34 & $6 \cdot 25$ & $6 \cdot 49$ & $6 \cdot 36$ & $0 \cdot 139$ & 0.43 & 0.38 & 0.89 \\
\hline $\mathrm{NH}_{3}-\mathrm{N}(\mathrm{mmol} / \mathrm{l})$ & $10 \cdot 6$ & $10 \cdot 3$ & $11 \cdot 0$ & 11.4 & 0.51 & 0.95 & 0.35 & 0.67 \\
\hline Volatile fatty acids $(\mathrm{mmol} / \mathrm{l})$ & 109 & 110 & 102 & 105 & 1.5 & $0 \cdot 19$ & $<0.001$ & 0.33 \\
\hline \multicolumn{9}{|l|}{ Molar proportions $(\mathrm{mmol} / \mathrm{mol})$} \\
\hline A & 664 & 658 & 669 & 668 & 3.0 & 0.21 & 0.006 & 0.56 \\
\hline $\mathrm{P}$ & 192 & 206 & 179 & 192 & 2.9 & $<0.001$ & $<0.001$ & 0.86 \\
\hline B & 109 & 103 & 114 & 105 & 1.7 & $<0.001$ & 0.05 & 0.39 \\
\hline Isobutyrate & 6.51 & 5.96 & 8.00 & 7.36 & 0.312 & 0.06 & $<0.001$ & 0.89 \\
\hline Valerate & 11.5 & $10 \cdot 3$ & $10 \cdot 7$ & $10 \cdot 6$ & 0.27 & 0.01 & 0.36 & 0.04 \\
\hline Isovalerate & 14.9 & $14 \cdot 1$ & 18.4 & $15 \cdot 2$ & 0.53 & $<0.001$ & $<0.001$ & 0.03 \\
\hline Lactate & 3.43 & $3 \cdot 18$ & 0.42 & 1.90 & 1.452 & 0.67 & 0.14 & 0.55 \\
\hline$A: P$ & 3.56 & $3 \cdot 26$ & 3.82 & 3.55 & 0.07 & $<0.001$ & $<0.001$ & 0.82 \\
\hline$P /(A+B)$ & 0.25 & 0.27 & 0.23 & 0.25 & 0.004 & $<0.001$ & $<0.001$ & 0.87 \\
\hline
\end{tabular}

A, acetate; $\mathrm{P}$, propionate; $\mathrm{B}$, butyrate. 
of valerate and isovalerate were observed, respectively, in cows fed HULL and COFO.

\section{Milk production and milk composition}

There was no interaction between flax hull supplementation and flax oil infusion for milk production and milk composition, except for the percentage of milk protein, which was lower in cows fed HULL than in those fed the other diets (Table 3). Flax hull supplementation had no effect on milk production, percentages of fat, lactose, urea $\mathrm{N}$, and total solids in milk and yield of milk components. However, flax hull supplementation decreased the yield of milk protein. Abomasal infusion of flax oil decreased milk production and had no effect on the percentages of fat, lactose and total solids in milk, which resulted in lower yield of milk components. Milk urea $\mathrm{N}$ content $(\mathrm{mg} / \mathrm{l})$ was increased and somatic cell counts tended $(P=0 \cdot 06)$ to increase with the infusion of flax oil in the abomasum.

\section{Milk fatty acid profile}

Flax hull supplementation decreased the proportions of SCFA $(6: 0,7: 0,8: 0,9: 0,10: 0,11: 0,12: 0$, cis-11 12:1 and 13:0) in milk fat, with the exception of the proportions of $4: 0$ and $5: 0$, which were unaffected (Table 4). Abomasal infusion of flax oil decreased the proportions of 5:0 in milk fat and had no effect on those of other SCFA. Feeding HUFO and CONT resulted in the lowest and highest proportions of mediumchain FA (cis-9 14:1, 15:0 and 16:0) in milk fat, respectively, as a result of the interaction between flax hull supplementation and flax oil infusion. Cows fed CONT had the highest proportion of cis-9 16:1 in milk fat, but there was no difference in the proportion of cis-9 16:1 in milk fat between cows fed HULL and those fed COFO and between cows fed COFO and those fed HUFO. Flax hull supplementation increased the proportion of trans-9 16:1 in milk fat; however, abomasal infusion of flax oil had no effect.
All eighteen-carbon FA in milk fat were affected by the diets. There was an interaction between flax hull supplementation and flax oil infusion for the proportions of 18:0 and cis-9 18:1 in milk fat as well as a trend for the proportions of trans- $13+14 \quad 18: 1+$ cis- $6+8 \quad 18: 1, \quad$ cis-9,cis-12 $18: 2$ and trans-9,trans-12 18:2 ( $P=0.09,0.05$ and 0.05 respectively). Flax hull supplementation increased the proportions of $18: 0$, trans $-918: 1$, trans-11 18:1, trans-13+14 $18: 1+$ cis- $6+818: 1$ and cis-9,trans-11 $18: 2$ in milk fat, while abomasal infusion of flax oil had the opposite effect. There was an interaction between flax hull supplementation and flax oil infusion for the proportions of cis-9,cis-12,cis-15 18:3 and cis-11, cis-14,cis-17 20:3 in milk fat, which resulted in the highest proportions when cows were fed COFO and HUFO and the lowest when cows were fed CONT. On the other hand, cows fed CONT had the highest proportion of cis-6,cis-9,cis-12 18:3 in milk fat, and there was no difference between cows fed COFO, HULL and HUFO.

\section{Expression of lipogenic enzymes in the mammary gland}

The addition of flax hulls to the diet (HULL) increased $(P<0.05)$ the mRNA abundance of lipogenic genes in mammary tissue, with the exception of $P P A R \gamma 2$, which was not affected by the treatment (Table 5). Abomasal infusion of flax oil (COFO) up-regulated the mRNA abundance of FASN, LPL and ACACA in mammary tissue and decreased the mRNA levels of PPAR 2 and $S C D$ when compared with CONT $(P<0.05)$. The addition of both flax hulls and flax oil to the diet (HUFO) increased the mRNA abundance of $A C A C A$ and PPAR 1 in mammary tissue and decreased the expression of $L P L$ and $S C D$ genes $(P<0 \cdot 05)$.

\section{Discussion}

PUFA have been shown to increase the peroxidation of tissues in sheep ${ }^{(2)}$ and steers ${ }^{(1)}$. In the present study, flax oil was infused in the abomasum of cows to increase the susceptibility

Table 3. Milk production and milk composition of Holstein cows fed diets containing no flax hulls (CONT), $9.88 \%$ flax hulls (HULL), no flax hulls and infused with $500 \mathrm{~g} / \mathrm{d}$ flax oil in the abomasum (COFO) or $9.88 \%$ flax hulls and infused with $500 \mathrm{~g} / \mathrm{d}$ flax oil in the abomasum (HUFO)

(Mean values with their overall standard errors)

\begin{tabular}{|c|c|c|c|c|c|c|c|c|}
\hline & \multicolumn{4}{|c|}{ Treatment } & \multirow[b]{2}{*}{ SEM } & \multicolumn{3}{|c|}{$P$} \\
\hline & CONT & HULL & COFO & HUFO & & Hull & Oil & Interaction \\
\hline Milk production (kg/d) & $29 \cdot 1$ & $29 \cdot 2$ & $26 \cdot 9$ & $26 \cdot 5$ & 0.65 & 0.70 & $<0.001$ & 0.59 \\
\hline \multicolumn{9}{|l|}{ Milk composition (\%) } \\
\hline Protein & 3.58 & 3.40 & $3 \cdot 61$ & 3.59 & 0.031 & 0.004 & 0.004 & 0.02 \\
\hline Fat & 3.29 & 3.46 & 3.44 & 3.44 & 0.114 & 0.29 & 0.71 & 0.56 \\
\hline Lactose & 4.66 & 4.64 & 4.66 & 4.68 & 0.035 & 0.99 & 0.47 & 0.59 \\
\hline Total solids & $12 \cdot 50$ & $12 \cdot 47$ & $12 \cdot 63$ & $12 \cdot 63$ & 0.133 & 0.96 & $0 \cdot 18$ & 0.71 \\
\hline Urea N (mg/l) & 103 & 94 & 120 & 112 & $5 \cdot 1$ & 0.15 & 0.004 & 0.89 \\
\hline \multicolumn{9}{|l|}{ Milk yield $(\mathrm{kg} / \mathrm{d})$} \\
\hline Protein & 1.04 & 0.99 & 0.96 & 0.94 & 0.011 & 0.03 & 0.001 & 0.30 \\
\hline Fat & 0.96 & 1.01 & 0.91 & 0.91 & 0.020 & 0.53 & 0.02 & 0.41 \\
\hline Lactose & $1 \cdot 36$ & 1.36 & 1.26 & 1.25 & 0.022 & 0.71 & $<0.001$ & 0.85 \\
\hline Total solids & 3.65 & 3.64 & 3.40 & 3.36 & 0.062 & 0.63 & $<0.001$ & 0.81 \\
\hline $\operatorname{SCS}^{*}$ & 1.77 & 1.47 & 2.52 & $2 \cdot 59$ & 0.483 & 0.77 & 0.06 & 0.71 \\
\hline
\end{tabular}

* Somatic cell score $=\log _{10}($ somatic cell count $/ \mathrm{ml})$. 
of their mammary tissue to lipoperoxidation. As another study ${ }^{(3)}$ has suggested that antioxidants may provide protection against the oxidative effect of diets rich in fat, flax hulls were fed to dairy cows to determine the potential of this rich source of antioxidants to limit peroxidation in mammary tissue.
Moreover, the fact that supplementation of flax hulls in the diet of dairy cows significantly increases the plasma concentration of enterolactone ${ }^{(23)}$, which is a strong antioxidant ${ }^{(20)}$, clearly justifies looking at flax products as a source of antioxidants. The infusion of flax oil was associated with a 6-fold

Table 4. Fatty acid profile of milk fat (percentage of total fatty acids) of Holstein cows fed diets containing no flax hulls (CONT), $9.88 \%$ flax hulls (HULL), no flax hulls and infused with $500 \mathrm{~g} / \mathrm{d}$ flax oil in the abomasum (COFO) or $9.88 \%$ flax hulls and infused with $500 \mathrm{~g} / \mathrm{d}$ flax oil in the abomasum (HUFO)

(Mean values with their overall standard errors)

\begin{tabular}{|c|c|c|c|c|c|c|c|c|}
\hline & \multicolumn{4}{|c|}{ Treatment } & \multirow[b]{2}{*}{ SEM } & \multicolumn{3}{|c|}{$P$} \\
\hline & CONT & HULL & COFO & HUFO & & Hull & Oil & Interaction \\
\hline $4: 0$ & 3.85 & 3.93 & 3.68 & $3 \cdot 78$ & 0.085 & 0.33 & 0.07 & 0.87 \\
\hline $5: 0$ & 0.04 & 0.02 & 0.01 & 0 & 0.010 & 0.16 & 0.02 & 0.54 \\
\hline $6: 0$ & $2 \cdot 23$ & $2 \cdot 01$ & $2 \cdot 17$ & 1.97 & 0.059 & 0.002 & 0.38 & 0.91 \\
\hline $7: 0$ & 0.05 & 0 & 0.02 & 0 & 0.016 & 0.026 & 0.28 & 0.28 \\
\hline $8: 0$ & 1.49 & $1 \cdot 23$ & 1.52 & $1 \cdot 27$ & 0.027 & $<0.001$ & 0.29 & 0.86 \\
\hline $9: 0$ & 0.17 & 0.05 & 0.14 & 0 & 0.035 & 0.001 & 0.27 & 0.72 \\
\hline $10: 0$ & $3 \cdot 28$ & $2 \cdot 35$ & $3 \cdot 32$ & 2.47 & 0.076 & $<0.001$ & 0.29 & 0.63 \\
\hline $11: 0$ & 0.25 & 0.15 & 0.25 & 0.18 & 0.021 & 0.001 & 0.52 & 0.52 \\
\hline $12: 0$ & 4.08 & $2 \cdot 74$ & 3.93 & $2 \cdot 78$ & 0.070 & $<0.001$ & 0.41 & 0.19 \\
\hline cis-11 12: 1 & 0.40 & 0.34 & 0.40 & 0.34 & 0.021 & 0.007 & 0.92 & 0.84 \\
\hline $13: 0$ & 0.26 & 0.22 & 0.25 & 0.21 & 0.009 & 0.0003 & 0.16 & 0.69 \\
\hline $14: 0$ & 11.55 & 8.97 & 9.56 & $7 \cdot 55$ & 0.200 & $<0.001$ & $<0.001$ & 0.16 \\
\hline cis-9 14: 1 & $1 \cdot 24$ & 0.90 & 0.81 & 0.64 & 0.023 & $<0.001$ & $<0.001$ & 0.002 \\
\hline $15: 0$ & $1 \cdot 17$ & 0.88 & 0.85 & 0.68 & 0.013 & $<0.001$ & $<0.001$ & 0.0002 \\
\hline $16: 0$ & $26 \cdot 74$ & 18.95 & 19.59 & 14.94 & 0.525 & $<0.001$ & $<0.001$ & 0.007 \\
\hline cis-9 16: 1 & 1.69 & $1 \cdot 18$ & 1.02 & 0.86 & 0.048 & $<0.001$ & $<0.001$ & 0.001 \\
\hline trans-9 16: 1 & 0.13 & 0.16 & 0.09 & $0 \cdot 15$ & 0.017 & 0.022 & 0.14 & 0.35 \\
\hline $17: 0$ & 0.64 & 0.52 & 0.47 & 0.46 & 0.031 & 0.04 & 0.003 & 0.09 \\
\hline $18: 0$ & $8 \cdot 31$ & $12 \cdot 88$ & $8 \cdot 36$ & $11 \cdot 76$ & 0.250 & $<0.001$ & 0.04 & 0.03 \\
\hline trans-9 18: 1 & 0.25 & 0.35 & 0.20 & 0.29 & 0.010 & $<0.001$ & $<0.001$ & 0.23 \\
\hline trans-10 $+1118: 1$ & 0.84 & $1 \cdot 31$ & 0.79 & $1 \cdot 18$ & 0.033 & $<0.001$ & 0.01 & 0.21 \\
\hline trans $-13+1418: 1+$ cis- $6+818: 1$ & 0.37 & 0.72 & 0.24 & 0.54 & 0.016 & 0 & $<0.001$ & 0.09 \\
\hline cis-9 18: 1 & $15 \cdot 11$ & $20 \cdot 87$ & 14.99 & $18 \cdot 50$ & 0.224 & 0 & $<0.001$ & 0.0001 \\
\hline cis-11 18: 1 & 0.48 & 0.43 & 0.59 & 0.51 & 0.052 & $0 \cdot 22$ & 0.08 & 0.76 \\
\hline cis-9, cis-12 $18: 2$ & $2 \cdot 07$ & $2 \cdot 02$ & $4 \cdot 81$ & $4 \cdot 25$ & 0.123 & 0.02 & $<0.001$ & 0.05 \\
\hline cis-9,trans-11 18:2 & 0.47 & 0.67 & 0.34 & 0.49 & 0.024 & $<0.001$ & $<0.001$ & 0.32 \\
\hline trans-9,trans-12 18:2 & 0.40 & 0.46 & 0.34 & 0.35 & 0.015 & 0.02 & $<0.001$ & 0.05 \\
\hline trans-10, cis-12 18:2 & 0 & 0 & 0 & 0 & & & & \\
\hline cis- 6, cis- 9, cis-12 18:3 & $0 \cdot 10$ & 0 & 0.02 & 0 & 0.016 & 0.002 & 0.01 & 0.01 \\
\hline cis- 9, cis- 12, cis-15 $18: 3$ & 0.98 & $1 \cdot 82$ & $11 \cdot 12$ & $10 \cdot 47$ & $0 \cdot 260$ & $0 \cdot 71$ & $<0.001$ & 0.01 \\
\hline $19: 0$ & 0.17 & 0.14 & $0 \cdot 13$ & 0.15 & 0.029 & 0.90 & 0.62 & 0.39 \\
\hline cis-7 19: 1 & 0.14 & 0.16 & 0.21 & 0.14 & 0.021 & 0.24 & 0.26 & 0.04 \\
\hline $20: 0$ & 0.44 & 0.45 & 0.49 & 0.43 & 0.017 & 0.18 & 0.45 & 0.07 \\
\hline cis-5 $20: 1$ & 0 & 0 & 0 & 0.04 & 0.020 & 0.33 & 0.33 & 0.33 \\
\hline cis-8 $20: 1$ & 0.23 & 0.19 & 0.19 & $0 \cdot 18$ & 0.019 & $0 \cdot 15$ & $0 \cdot 22$ & 0.34 \\
\hline cis-11 $20: 1$ & 0.01 & 0 & 0 & 0 & 0.003 & 0.33 & 0.33 & 0.33 \\
\hline cis- 11, cis-14 $20: 2$ & 0.22 & 0.20 & 0.27 & 0.22 & 0.020 & 0.14 & $0 \cdot 10$ & 0.32 \\
\hline cis- 11, cis-14 cis-17 $20: 3$ & 0.06 & 0.29 & 0.58 & 0.51 & 0.045 & 0.09 & $<0.0001$ & 0.003 \\
\hline cis-8, cis-11, cis-14 $20: 3$ & 0.18 & 0.13 & 0.15 & 0.13 & 0.016 & 0.03 & 0.37 & 0.36 \\
\hline cis-5, cis-8, cis-11, cis-14 $20: 4$ & 0.20 & 0.16 & 0.20 & 0.16 & 0.009 & 0.001 & 0.90 & 0.69 \\
\hline cis- 5, cis-8, cis- 11 , cis- 14, cis- $1720: 5$ & $0 \cdot 29$ & 0.25 & 0.35 & 0.27 & 0.024 & 0.03 & 0.11 & 0.41 \\
\hline $22: 0$ & 0.25 & 0.25 & 0.28 & 0.24 & 0.010 & 0.04 & 0.25 & 0.04 \\
\hline cis-7, cis-10, cis-13, cis-16 $22: 4$ & 0.03 & 0.02 & 0 & 0 & 0.012 & 0.62 & 0.05 & 0.62 \\
\hline Cis-7, cis-10, cis-13, cis-16, cis-19 $22: 5$ & 0.33 & 0.29 & 0.35 & $0 \cdot 30$ & 0.024 & 0.05 & 0.63 & 0.92 \\
\hline $24: 0$ & $0 \cdot 21$ & 0.28 & 0.32 & $0 \cdot 21$ & 0.038 & 0.54 & 0.59 & 0.02 \\
\hline Total unidentified & 8.58 & 11.03 & 6.59 & $10 \cdot 39$ & 0.956 & 0.004 & 0.18 & 0.48 \\
\hline Total trans & $2 \cdot 08$ & 2.95 & $1 \cdot 76$ & $2 \cdot 45$ & 0.056 & $<0.001$ & $<0.001$ & 0.11 \\
\hline SCFA* & $16 \cdot 12$ & 13.05 & $15 \cdot 69$ & 12.99 & 0.290 & $<0.001$ & 0.40 & 0.52 \\
\hline MCFA† & 43.15 & 31.56 & $32 \cdot 40$ & $25 \cdot 29$ & 0.628 & $<0.001$ & $<0.001$ & 0.002 \\
\hline LCFA‡ & $32 \cdot 14$ & $44 \cdot 37$ & $45 \cdot 32$ & $51 \cdot 33$ & 0.608 & $<0.001$ & $<0.001$ & 0.0001 \\
\hline MUFA§ & $20 \cdot 88$ & $26 \cdot 61$ & $19 \cdot 53$ & $23 \cdot 37$ & 0.268 & $<0.001$ & $<0.001$ & 0.002 \\
\hline PUFA\| & $5 \cdot 04$ & $6 \cdot 07$ & $18 \cdot 17$ & $16 \cdot 88$ & 0.335 & 0.70 & $<0.001$ & 0.002 \\
\hline PUFA:SFA & 0.08 & 0.11 & 0.33 & 0.35 & 0.009 & 0.01 & $<0.001$ & 0.45 \\
\hline SFAף & $65 \cdot 20$ & $56 \cdot 03$ & $55 \cdot 36$ & 49.09 & 0.892 & $<0.001$ & $<0.001$ & 0.12 \\
\hline$n-3$ & 1.04 & $2 \cdot 11$ & 11.69 & $10 \cdot 97$ & 0.259 & 0.50 & $<0.001$ & 0.002 \\
\hline$n-6$ & $3 \cdot 32$ & 3.09 & $5 \cdot 87$ & $5 \cdot 20$ & 0.110 & $<0.001$ & $<0.001$ & 0.06 \\
\hline$n-6: n-3$ & $3 \cdot 34$ & 1.52 & 0.50 & 0.47 & 0.130 & $<0.001$ & $<0.001$ & $<0.0001$ \\
\hline
\end{tabular}


Table 4. Continued

\begin{tabular}{|c|c|c|c|c|c|c|c|c|}
\hline & \multicolumn{4}{|c|}{ Treatment } & \multirow[b]{2}{*}{ SEM } & \multicolumn{3}{|c|}{$P$} \\
\hline & CONT & HULL & COFO & HUFO & & Hull & Oil & Interaction \\
\hline Ratios & & & & & & & $<0.001$ & \\
\hline cis-9 14:1/14:0 & 0.11 & 0.10 & 0.09 & 0.09 & 0.003 & 0.245 & $<0.001$ & 0.21 \\
\hline cis-9 16:1/16:1 & 0.06 & 0.06 & 0.05 & 0.06 & 0.003 & 0.470 & 0.014 & 0.25 \\
\hline cis-9 18:1/18:0 & 1.83 & 1.63 & 1.81 & 1.61 & 0.036 & $<0.001$ & 0.44 & 0.98 \\
\hline cis-9,trans-11 18:2/trans-11 $18: 1$ & 0.56 & 0.51 & 0.43 & 0.42 & 0.010 & 0.005 & $<0.001$ & 0.07 \\
\hline
\end{tabular}

MCFA, medium-chain fatty acids; LCFA, long-chain fatty acids.

* $4: 0+5: 0+6: 0+7: 0+8: 0+9: 0+10: 0+11: 0+12: 0+$ cis-11 $12: 1+13: 0$.

$+14: 0+$ cis-9 $14: 1+15: 0+16: 0+$ cis-9 $16: 1+$ trans-9 $16: 1+17: 0$.

$\ddagger 18: 0+$ trans $-9 \quad 18: 1+$ trans- $10+11 \quad 18: 1+$ trans $-13+14 \quad 18: 1+$ cis- $6+8 \quad 18: 1+$ cis-9 $\quad 18: 1+$ cis- $11 \quad 18: 1+$ cis-9,cis-12 $18: 2+$ cis-9,trans- 11 $18: 2+$ trans-9,trans-12 $18: 2+$ trans-10,cis-12 $18: 2+$ cis- 6, cis-9,cis-12 $18: 3+$ cis-9,cis- 12, cis- $1518: 3+19: 0+$ cis-7 $19: 1+20: 0+$ cis-5 $20: 1+$ cis-8

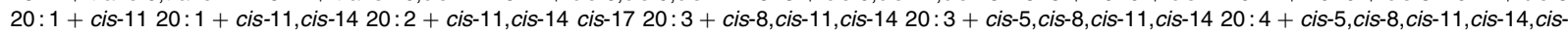
$1720: 5+22: 0+$ cis-7, cis-10, cis-13, cis-16 22:4 + cis-7, cis-10, cis-13,cis-16, cis-19 $22: 5+24: 0$.

$\S$ cis-11 $12: 1+$ cis-9 $14: 1+$ cis-9 16:1+ trans-9 16:1+ trans-9 18:1+trans-10 + 11 18:1+trans-13+14 18:1+ cis-6 + $818: 1+$ cis-9 $18: 1+$ cis- 11 $18: 1+$ cis-7 $19: 1+$ cis-5 $20: 1+$ cis-8 $20: 1+$ cis-11 $20: 1$.

|| cis-9,cis-12 18:2 + cis-9,trans-11 18:2 + trans-9,trans-12 18:2+cis-6,cis-9,cis-12 18:3+ cis-9,cis-12,cis-15 18:3+ cis-11,14 20:2 + cis-11,cis-14 cis-17

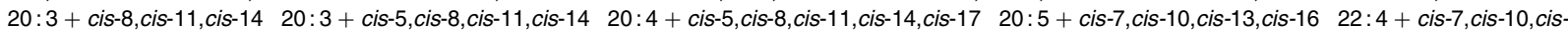
13, cis- 16, cis-19 $22: 5$.

I $4: 0+5: 0+6: 0+7: 0+8: 0+9: 0+10: 0+11: 0+12: 0+13: 0+14: 0+15: 0+16: 0+17: 0+18: 0+19: 0+20: 0+22: 0+24: 0$.

increase in the proportion of linolenic acid (cis-9,cis-12,cis-15 18:3) in milk fat, which is in agreement with previous observations made by Côrtes et al. ${ }^{(27)}$ in dairy cows that were infused with 250 or $500 \mathrm{~g}$ flax oil/d in the abomasum. This is also in agreement with the finding of an increase in the proportion of linolenic acid in the plasma of sheep infused with flax oil in the duodenum, which was related to a higher susceptibility of plasma lipids to lipoperoxidation ${ }^{(2)}$.

In the present study, the lower intake of DM, expressed as a percentage of body weight, in cows infused with flax oil (COFO and HUFO) when compared with those not infused with flax oil (CONT and HULL) may be the result of a higher amount of fat reaching the small intestine as reported previously ${ }^{(27)}$. Lower milk yield with the infusion of flax oil in the abomasum is in agreement with the results reported by Khas-Erdene et al. ${ }^{(36)}$, who infused a free FA mixture of linolenic acid, although the proportion of fat was not affected in the present study. The effects of flax hull supplementation and abomasal infusion of flax oil on milk FA profile were similar to those reported by Côrtes et $a l^{(27)}$.

In the present study, higher total VFA concentration in cows not infused with flax oil was probably a result of higher numerical DM intake. The molar proportion of propionate increased with flax hull supplementation as reported previously by da Silva-Kazama et al. ${ }^{(37)}$. As flax hulls contain $54.3 \%$ linolenic acid as a percentage of total FA, this FA may be responsible for these changes. It is unclear whether a change in the bacterial community or other mechanisms (e.g. change in substrate fermentation resulting from a lower intake of DM, expressed as a percentage of body weight) were responsible for the increased concentrations of butyrate and isovalerate in cows infused with flax oil. The lower molar proportions of acetate, butyrate and isobutyrate and higher proportion of propionate in cows not infused with flax oil in the abomasum were probably a result of numerical differences in DM intake.

In the present study, a higher mRNA abundance of SREBF1, FASN, LPL, PPAR $1, S C D$ and ACACA, but not of PPAR $\gamma 2$, was observed in cows fed HULL than in those fed CONT.
As FASN and ACACA are known to be involved in de novo FA synthesis $^{(38)}$, up-regulation of these genes was unexpected. Indeed, according to the proportions of SCFA in milk fat, the lowest de novo synthesis of FA was observed in cows fed HULL. A similar decrease in the proportions of SCFA and

Table 5. Relative quantification of the mRNA of lipogenic genes in the mammary gland of Holstein cows fed diets containing no flax hulls (CONT), $9.88 \%$ flax hulls (HULL), no flax hulls and infused with $500 \mathrm{~g} / \mathrm{d}$ flax oil in the abomasum (COFO) or $9.88 \%$ flax hulls and infused with $500 \mathrm{~g} / \mathrm{d}$ flax oil in the abomasum (HUFO)

\begin{tabular}{|c|c|c|c|c|}
\hline Genes & Treatments & $R Q_{\min }$ & $\mathrm{RQ}^{*}$ & $R Q_{\max }$ \\
\hline \multirow[t]{3}{*}{ SREBF1 } & COFO & 0.954 & 1.016 & 1.082 \\
\hline & HULL† & $2 \cdot 202$ & $2 \cdot 382$ & 2.576 \\
\hline & HUFO & 0.888 & 0.965 & 1.048 \\
\hline \multirow[t]{3}{*}{ FASN } & COFO† & 1.379 & 1.534 & 1.706 \\
\hline & HULL† & $3 \cdot 100$ & $3 \cdot 310$ & 3.535 \\
\hline & HUFO & 0.922 & 0.986 & 1.054 \\
\hline \multirow[t]{3}{*}{$L P L$} & COFO† & $1 \cdot 270$ & 1.339 & 1.411 \\
\hline & HULL† & $7 \cdot 833$ & 8.336 & 8.872 \\
\hline & HUFO & 0.745 & 0.795 & 0.848 \\
\hline \multirow[t]{3}{*}{$P P A R \gamma 1$} & COFO & 0.942 & 0.999 & 1.060 \\
\hline & HULL† & $2 \cdot 485$ & $2 \cdot 673$ & $2 \cdot 876$ \\
\hline & HUFO† & 1.091 & $1 \cdot 177$ & $1 \cdot 270$ \\
\hline \multirow[t]{3}{*}{$P P A R \gamma 2$} & COFO‡ & 0.681 & 0.755 & 0.837 \\
\hline & HULL & 0.727 & 0.858 & 1.013 \\
\hline & HUFO & 0.858 & 0.975 & 1.106 \\
\hline \multirow[t]{3}{*}{$S C D$} & COFO & 0.826 & 0.887 & 0.953 \\
\hline & HULL† & 3.925 & $4 \cdot 199$ & 4.493 \\
\hline & HUFO $\ddagger$ & 0.629 & 0.680 & 0.735 \\
\hline \multirow[t]{3}{*}{$A C A C A$} & COFO† & $1 \cdot 208$ & $1 \cdot 320$ & 1.443 \\
\hline & HULL† & 4.054 & $4 \cdot 349$ & 4.667 \\
\hline & HUFO† & 1.396 & 1.516 & 1.646 \\
\hline
\end{tabular}

$\mathrm{RQ}$, relative quantification; SREBF1, sterol regulatory element binding transcription factor $1 ; F A S N$, fatty acid synthase; $L P L$, lipoprotein lipase; $S C D$, stearoyl-CoA desaturase (delta-9desaturase); ACACA, acetyl-CoA carboxylase- $\alpha$.

${ }^{*} \mathrm{RQ}$ of mRNA abundance using the comparative cycle threshold method and the control (CONT) treatment as reference. Values represent fold values relative to CONT with their corresponding $R Q_{\min }$ and $R Q_{\max }$. Significant differences are observed when the range $\left(R Q_{\min }-R Q_{\max }\right)$ does not include the value 1 .

†Up-regulated genes $(P<0.05)$

$\ddagger$ Down-regulated genes $(P<0 \cdot 05)$. 
medium-chain FA in milk fat with flax hull supplementation has been reported previously ${ }^{(27)}$, thus reflecting reduced de novo FA synthesis. The FASN, LPL, SCD and ACACA genes are known downstream targets of SREBF1 and PPAR $\gamma$ transcription factors, both of which are involved in FA synthesis $^{(38,39)}$. In accordance with these studies, we found the mRNA levels of SERBF1 and PPAR 1 to be up-regulated in parallel with the mRNA abundance of FASN, $L P L, S C D$ and $A C A C A$. However, the reason for the lack of a treatment effect on the mRNA abundance of $P P A R \gamma 2$ remains to be determined. Nevertheless, rosiglitazone, a specific agonist of PPAR $\gamma$, has been shown to up-regulate the expression of SREBF1, FASN, $S C D$ and $A C A C A$ genes when added to bovine mammary epithelial cells ${ }^{(39)}$. However, the activation of PPAR $\gamma$ with rosiglitazone does not allow discriminating between the different PPAR $\gamma$ isoforms involved.

Flax hulls are a rich source of plant lignans, including the glycosides of secoisolariciresinol and matairesinol, which have strong antioxidant properties ${ }^{(16)}$. In the rumen, plant lignans are mainly converted into the mammalian lignan enterolactone, a polyphenol metabolite ${ }^{(17)}$. The presence of these polyphenol compounds in dairy cows fed HULL may account for the increases in the levels of some lipogenic gene transcripts. For example, Chen et al. ${ }^{(22)}$ had previously observed a higher hepatic mRNA abundance of SREBF1, FASN and ACACA in rats fed green and black tea and higher mRNA levels of $P P A R \gamma$ in the adipose tissue of rats fed black tea or epigallocatechin-3-gallate, which are all polyphenol-rich compounds leading to enterolactone production. Similar increases in the mRNA abundance of $L P L$ and $S C D$ in the adipose tissue of rats have been observed with the addition of sesame lignans to the diet, whereas lignans have been found to reduce the mRNA levels of $A C A C A$ in the liver ${ }^{(9)}$.

The increase in the mRNA abundance of SREBF1, FASN, $L P L, P P A R \gamma 1, S C D$ and ACACA observed when cows were fed only flax hulls (HULL) was affected by the infusion of flax oil. Indeed, compared to cows fed the CONT diet, the increase in mRNA abundance of genes observed when only hulls were supplemented was changed for a decrease ( $L P L$ and $S C D)$, moderate increase (PPAR 1 and $A C A C A)$ and lack of effect (SREBF1 and $F A S N$ ) on mRNA abundance when hulls were combined with infusion of oil with the HUFO diet. Therefore, infusion of flax oil in the abomasum of cows that were fed flax hulls contributed to the downregulation of the expression of lipogenic genes. This is in agreement with several studies that have reported a downregulation of the expression of lipogenic genes with the addition of PUFA. For example, the transcriptional activity of SREBF1 promoter has been reported to be down-regulated in rat hepatocytes incubated with linolenic acid, $\gamma$-linolenic acid and $\mathrm{EPA}^{(40)}$. Moreover, the addition of PUFA to HEK-293 cells has also been shown to result in lower mRNA levels of $S R E B F 1^{(41)}$, and rats fed $n-6$ or $n-3$ PUFA have been found to exhibit a reduced mRNA abundance of both SREBF1 and FASN in hepatic tissue ${ }^{(42)}$.

When flax oil was infused in the abomasum of cows fed CONT (e.g. COFO treatment), the mRNA abundance of SREBF1 and PPAR 11 transcription factors was not affected by flax oil infusion, whereas the transcript abundance of $P P A R \gamma 2$ was down-regulated. Conversely, when compared with cows fed CONT, cows fed COFO exhibited an increased expression of FASN and ACACA genes, which are involved in de novo FA synthesis. This was unexpected, as these two genes are known downstream targets of SERBF1 and PPAR $\gamma$ transcription factors, and flax oil infusion had no effect on the proportions of SCFA, which are synthesised de novo in mammary tissue, in milk fat. A possible explanation may be that the effects of dietary FA on SREBF1 and PPAR $\gamma$ are mediated through changes in activity rather than changes in transcript abundance. Interestingly, Bernard et al. ${ }^{(43)}$ observed a reduction in the de novo synthesis of SCFA in the milk fat of goats fed sunflower oil or linseed oil, and the reduction was found to be independent of the mRNA expression of $A C A C A$ and FASN. This suggests that the expression of $A C A C A$ and $F A S N$ gene is not always related to the secretion of SCFA in milk fat. The present results are in contrast with those reported by Ahnadi et al. ${ }^{(44)}$, who observed a decrease in the proportions of SCFA in milk fat and mRNA abundance of $A C A C A, F A S N, S C D$ and $L P L$ in the mammary tissue of dairy cows fed a diet supplemented with fish oil; however, the effect of fish oil on the mRNA abundance of $L P L$ and SCD was dependent on the protection provided by oil against biohydrogenation by rumen microbes (e.g. unprotected $v$. glutaraldehyde-protected (protection level $>90 \%$ ) fish oil). In another study ${ }^{(45)}$, goats fed formaldehyde-treated linseed were found to exhibit a higher expression of LPL in mammary tissue compared with those fed a control diet, whereas the expression of SCD was reduced and that of FASN and ACACA was not affected.

Compared with cows fed CONT, cows fed COFO and HUFO had a lower mRNA abundance of $S C D$ in mammary tissue. Similar reductions in the mRNA levels of $S C D$ in the mammary tissue of goats fed formaldehyde-treated linseed or oleic sunflower oil have been reported ${ }^{(45)}$. Cows fed rumen-protected fish oil have also been shown to have reduced mRNA abundance of $S C D$ in mammary tissue ${ }^{(44)}$. As SCD is involved in the synthesis of MUFA such as cis-9 16:1, cis-9 18:1 and the cis-9,trans-11 18:2 conjugated linoleic $\operatorname{acid}^{(46)}$, this may partly explain the lower proportions of MUFA in the milk fat of cows infused with flax oil in the abomasum. However, a decrease in the proportions of MUFA could also be due to a dilution effect, as the proportions of PUFA in milk fat were increased by more than $10 \%$. The ratios of cis-9 $14: 1 / 14: 0$, cis- $916: 1 / 16: 0$, cis- 9 and trans-11 18:2/trans-11 18:1, which can be used as a proxy of SCD activity $^{(47)}$, also decreased with the infusion of flax oil in the abomasum. Altogether, these results suggest that PUFA bypassing the rumen decrease the transcript abundance of $S C D$ (as shown in the present study) and the activity of $\mathrm{SCD}^{(44)}$ in the mammary tissue of dairy cows, which lower the proportions of MUFA in milk fat as observed in the present study.

The higher mRNA abundance of $L P L$ in mammary tissue and proportions of long-chain FA in the milk fat of cows fed the COFO than in those fed CONT may reflect a higher need for LPL enzyme in blood TAG uptake with an increase in the levels of dietary PUFA. Similar increases in the mRNA 
abundance and activity of mammary LPL and proportions of long-chain FA in milk fat have been observed in goats fed formaldehyde-treated oleic sunflower oil ${ }^{(45)}$. However, the addition of unprotected flax oil or sunflower oil has been found to have no effect on the activity and mRNA abundance of LPL in the mammary tissue of goats ${ }^{(43)}$. These results suggest that the biohydrogenation of PUFA by the ruminal microbiota affects the transcript abundance and activity of the $L P L$ gene.

Flax hulls contain $29.8 \%$ lipids and high proportions of PUFA, which may also affect the expression of lipogenic genes ${ }^{(48)}$. In the present study, FA from flax hulls were subjected to biohydrogenation by the rumen microbiota, while FA from flax oil bypassed the rumen (COFO and HUFO). With HUFO, PUFA originating from flax hulls were subjected to biohydrogenation, while those present in flax oil were not, which resulted in the highest proportions of total trans FA in milk fat in cows fed HULL followed by those fed HUFO. Moreover, the highest proportions of biohydrogenation intermediates, such as trans-11 18:1, trans-9 18:1, cis-9,trans-11 18:2 and trans-9,trans-12 18:2, were found in the milk fat of cows fed HULL. Therefore, differences in biohydrogenation intermediates observed in milk fat may account for some of the differences in the mRNA abundance of lipogenic genes when cows were fed COFO or HUFO $v$. CONT. Indeed, several studies have established that biohydrogenation intermediates can affect lipogenesis in mammary tissue and modulate the expression and activity of lipogenic genes ${ }^{(49,50)}$.

\section{Acknowledgements}

In conclusion, the results of the present study indicated that the mRNA levels of SERBF1 and PPAR 1 1 were up-regulated in parallel with the mRNA abundance of FASN, LPL, SCD and $A C A C A$ when cows were fed flax hulls, corroborating that the FASN, LPL, SCD and ACACA genes are the downstream targets of SREBF1 and PPAR $\gamma$ transcription factors. However, when compared with cows fed the control diet, cows fed the control diet with the infusion of oil exhibited an increased expression of FASN and ACACA genes, which was unexpected. Therefore, the measurement of activity rather than that of the abundance of transcripts may be more important to determine the effects of dietary FA on genes involved in lipogenesis. The present study shows that flax hulls with or without flax oil bypassing the rumen can affect the expression of lipogenic genes in the mammary tissue of dairy cows. However, more information is required to better predict which constituent of flax hulls and flax oil is responsible for the observed effects on lipogenic gene expression and milk FA profile.

C. C. was a recipient of a fellowship from the National Science and Engineering Research Council of Canada. The present study was funded by Agriculture and Agri-Food Canada, which was aware of, but did not influence the trial design and had no role in the data analysis and interpretation.

The authors express their gratitude to the staff of the Dairy and Swine Research and Development Centre for their contribution to the present study. They cordially thank Véronique Roy, Liette Veilleux, Danielle Beaudry and Sylvie Dallaire for their technical assistance and Steve Méthot for his help in the statistical analysis.
The authors' contributions are as follows: M.-F. P., C. C. and H. V. P. drafted the manuscript; H. V. P. and M.-F. P. conceived and directed the study; C. C. coordinated the study and was in charge of the infusions and of collecting data from animals; C. B. contributed to the conception and design of the experiment and to the interpretation and discussion of the results; P. L. carried out the mammary biopsies. All the authors were involved in the revision of the paper and approved the final version of the paper.

None of the authors has a personal or professional conflict of interest.

\section{References}

1. Scislowski V, Bauchart D, Gruffat D, et al. (2005) Effects of dietary $n-6$ or $n-3$ polyunsaturated fatty acids protected or not against ruminal hydrogenation on plasma lipids and their susceptibility to peroxidation in fattening steers. J Anim Sci 83, 2162-2174.

2. Gladine C, Rock E, Morand C, et al. (2007) Bioavailability and antioxidant capacity of plant extracts rich in polyphenols, given as a single acute dose, in sheep made highly susceptible to lipoperoxidation. Br J Nutr 98, 691-701.

3. Sies H, Stahl W \& Sevanian A (2005) Nutritional, dietary and postprandial oxidative stress. J Nutr 135, 969-972.

4. Frankel EN (2005) Lipid Oxidation, 2nd ed., pp. 13-22 [EN Frankel, editor]. Bridgwater: The Oily Press.

5. Vázquez-Añón M, Nocek J, Bowman G, et al. (2008) Effects of feeding a dietary antioxidant in diets with oxidized fat on lactation performance and antioxidant status of the cow. J Dairy Sci 91, 3165-3172.

6. Bernabucci U, Ronchi B, Lacetera N, et al. (2005) Influence of body condition score on relationships between metabolic status and oxidative stress in periparturient dairy cows. J Dairy Sci 88, 2017-2026.

7. Aitken SL, Karcher EL, Rezamand P, et al. (2009) Evaluation of antioxidant and proinflammatory gene expression in bovine mammary tissue during the periparturient period. J Dairy Sci 92, 589-598.

8. Kiso Y (2004) Antioxidative roles of sesamin, a functional lignan in sesame seed, and its effect on lipid- and alcohol-metabolism in the liver: a DNA microarray study. Biofactors 21, 191-196.

9. Ide T, Lim JS, Odbayar TO, et al. (2009) Comparative study of sesame lignans (Sesamin, Episesamin and Sesamolin) affecting gene expression profile and fatty acid oxidation in rat liver. $J$ Nutr Sci Vitaminol 55, 31-43.

10. Baum SJ \& Hamm A (2012) Fatty acids and their derivatives in cardiovascular disease: arachidonic, eicosapentaenoic, and docosahexaenoic acids and their byproducts, the eicosanoids and docosanoids. Curr Cardiovasc Risk Rep 6, 146-154.

11. Stephenson JA, Al-Taan O, Arshad A, et al. (2013) The multifaceted effects of omega-3 polyunsaturated fatty acids on the hallmarks of cancer. J Lipids 2013, 261247.

12. Wood JD \& Enser M (1997) Factors influencing fatty acids in meat and the role of antioxidants in improving meat quality. Br J Nutr 78, S49-S60.

13. Kouba M \& Mourot J (2011) A review of nutritional effects on fat composition of animal products with special emphasis on n-3 polyunsaturated fatty acids. Biochimie 93, 13-17.

14. Petit HV (2002) Digestion, milk production, milk composition and blood composition of dairy cows fed whole flaxseed. J Dairy Sci 85, 1482-1490.

15. Timmons JS, Weiss WP, Palmquist DL, et al. (2001) Relationships among dietary roasted soybeans, milk 
components, and spontaneous oxidized flavor of milk. J Dairy Sci 84, 2440-2449.

16. Mazur W, Fotsis T, Wähälä K, et al. (1996) Isotope dilution gas chromatographic-mass spectrometric method for the determination of isoflavonoids, coumestrol, and lignans in food samples. Anal Biochem 233, 169-180.

17. Gagnon N, Côrtes C, Da Silva D, et al. (2009) Ruminal metabolism of flaxseed Linum usitatissimum lignans to the mammalian lignan enterolactone and its concentration in ruminal fluid, plasma, urine and milk of dairy cows. $\mathrm{Br} \mathrm{J}$ Nutr 102, 1015-1023.

18. Petit HV, Gagnon N, Priyadarshini SM, et al. (2009) Milk concentration of the mammalian lignan enterolactone milk production milk fatty acid profile and digestibility in dairy cows fed diets containing whole flaxseed or flaxseed meal. J Dairy Res 76, 257-264.

19. Adlercreutz H \& Mazur W (1997) Phyto-oestrogens and Western diseases. Ann Med 29, 95-120.

20. Prasad K (2000) Antioxidant activity of secoisolariciresinol diglucoside-derived metabolites, secoisolariciresinol, enterodiol, and enterolactone. Int J Angiol 9, 220-225.

21. Gobert M, Martin B, Ferlay A, et al. (2009) Plant polyphenols associated with vitamin $\mathrm{E}$ can reduce plasma lipoperoxidation in dairy cows given $n-3$ polyunsaturated fatty acids. J Dairy Sci 92, 6095-6104.

22. Chen N, Bezzina R, Hinch E, et al. (2009) Green tea, black tea, and epigallocatechin modify body composition, improve glucose tolerance, and differentially alter metabolic gene expression in rats fed a high-fat diet. Nutr Res 29, 784-793.

23. Côrtes C, Palin MF, Gagnon N, et al. (2012) Mammary gene expression and activity of antioxidant enzymes and concentration of the mammalian lignan enterolactone in milk and plasma of dairy cows fed flax lignans and infused with flax oil in the abomasum. Br J Nutr 108, 1390-1398.

24. National Research Council (2001) Nutrient Requirements of Dairy Cattle, 7th ed. Washington, DC: The National Academies Press.

25. CCAC (Canadian Council on Animal Care) (1993) Guide to Care and Use of Experimental Animals [ED Offert, BM Cross and AA McWilliam, editors]. Ottawa, ON: CCAC.

26. Côrtes C, da Silva-Kazama DC, Kazama R, et al. (2010) Milk composition, milk fatty acid profile, digestion, and ruminal fermentation in dairy cows fed whole flaxseed and calcium salts of flaxseed oil. J Dairy Sci 93, 3146-3157.

27. Côrtes C, Kazama R, da Silva-Kazama DC, et al. (2011) Digestion, milk production and milk fatty acid profile of dairy cows fed flax hulls and infused with flax oil in the abomasum. J Dairy Res 78, 293-300.

28. Farr VC, Stelwagen K, Cate LR, et al. (1996) An improved method for the routine biopsy of bovine mammary tissue. J Dairy Sci 79, 543-549.

29. Association of Official Analytical Chemists (AOAC) (1990) Official Methods of Analysis, 15th ed. Washington, DC: AOAC.

30. Fenton TW \& Fenton M (1979) An improved procedure for the determination of chromic oxide in feed and feces. Can J Anim Sci 59, 631-634

31. Novozamsky I, Van Eck R, Van Schouwenburg JC, et al. (1974) Total nitrogen determination in plant material by means of the indophenol-blue method. Neth J Agric Sci 22, 3-5.

32. Chouinard PY, Lévesque J, Girard V, et al. (1997) Dietary soybeans extruded at different temperatures: milk composition and in situ fatty acid reactions. J Dairy Sci 80, 2913-2924.
33. Park PW \& Goins RE (1994) In situ preparation of fatty acid methyl esters for analysis of fatty acid composition in foods. J Food Sci 59, 1262-1266.

34. Labrecque B, Beaudry D, Mayhue M, et al. (2009) Molecular characterization and expression analysis of the porcine paraoxonase 3 (PON3) gene. Gene 443, 110-120.

35. Andersen CL, Jensen JL \& Orntoft TF (2004) Normalization of real-time quantitative reverse transcription-PCR data: a model-based variance estimation approach to identify genes suited for normalization, applied to bladder and colon cancer data sets. Cancer Res 64, 5245-5250.

36. Khas-Erdene Q, Wang JQ, Bu DP, et al. (2010) Short Communication: responses to increasing amounts of free $\alpha$-linolenic acid infused into the duodenum of lactating dairy cows. J Dairy Sci 93, 1677-1684.

37. da Silva-Kazama DC, Côrtes C, Kazama R, et al. (2011) Ruminal fermentation characteristics and fatty acid profile of ruminal fluid and milk of dairy cows fed flaxseed hulls supplemented with monensin. J Dairy Res 78, 56-62.

38. Harvatine KJ, Boisclair YR \& Bauman DE (2009) Recent advances in the regulation of milk fat synthesis. Animal 3, 40-54.

39. Kadegowda AKG, Bionaz M, Piperova LS, et al. (2009) Peroxisome proliferator-activated receptor- $\gamma$ activation and longchain fatty acids alter lipogenic gene networks in bovine mammary epithelial cells to various extents. J Dairy Sci 92, 4276-4289.

40. Deng X, Cagen LM, Wilcox HG, et al. (2002) Regulation of the rat SREBP-1c promoter in primary rat hepatocytes. Biochem Biophys Res Commun 290, 256-262.

41. Hannah VC, Ou J, Luong A, et al. (2001) Unsaturated fatty acids down-regulate SREBP isoforms $1 \mathrm{a}$ and $1 \mathrm{c}$ by two mechanisms in HEK-293 Cells. J Biol Chem 276, 4365-4372.

42. Xu J, Nakamura MT, Cho HP, et al. (1999) Sterol regulatory element binding protein-1 expression is suppressed by dietary polyunsaturated fatty acids. A mechanism for the coordinate suppression of lipogenic genes by polyunsaturated fats. J Biol Chem 274, 23577-23583.

43. Bernard L, Leroux C, Faulconnier Y, et al. (2009) Effect of sunflower-seed oil or linseed oil on milk fatty acid secretion and lipogenic gene expression in goats fed hay-based diets. J Dairy Res 76, 241-248.

44. Ahnadi CE, Beswick N, Delbecchi L, et al. (2002) Addition of fish oil to diets for dairy cows. II. Effects on milk fat and gene expression of mammary lipogenic enzymes. $J$ Dairy Res 69, 521-531.

45. Bernard L, Rouel J, Leroux C, et al. (2005) Mammary lipid metabolism and milk fatty acid secretion in alpine goats fed vegetable lipids. J Dairy Sci 88, 1478-1489.

46. Corl BA, Baumgard LH, Dwyer DA, et al. (2001) The role of $\Delta$ 9-desaturase in the production of cis-9, trans-11 CLA. J Nutr Biochem 12, 622-630.

47. Bernard L, Leroux C \& Chilliard Y (2008) Expression and nutritional regulation of lipogenic genes in the ruminant lactating mammary gland. Adv Exp Med Biol 606, 67-108.

48. Prado IM \& Saldana MDA (2012) Extraction of phenolic compounds and polysaccharides from flaxseed hulls by hot pressurized water. 10th International Symposium on Supercritical Fluids (ISSF2012), 13-16 May 2012, San Francisco, CA, P-0420.

49. Shingfield KJ, Bernard L, Leroux C, et al. (2010) Role of trans fatty acids in the nutritional regulation of mammary lipogenesis in ruminants. Animal 4, 1140-1166.

50. Mach N, Goselink RMA, van Baal J, et al. (2013) Relationship between milk fatty acid composition and the expression of lipogenic genes in the mammary gland of dairy cows. Livest Sci 151, 92-96. 